\title{
PENGARUH PEMUPUKAN N DAN FREKUENSI PEMANGKASAN TAJUK PADA ASPEK AGRONOMIS DAN HASIL TANAMAN UBI JALAR \\ (Ipomoea batatas (L.) Lam.) var. KRETEK
}

\section{EFFECT OF NITROGEN APPLICATION AND FREQUENCY OF TOPPING ON AGRONOMIC ASPECTS AND YIELD OF SWEET POTATO (Ipomoea batatas (L.) Lam.) var. KRETEK}

\author{
Nur Edy Suminarti \\ Dosen Fakultas Pertanian Universitas Brawijaya \\ Jl. Veteran, Malang 65145 Jawa Timur, Indonesia \\ Korespondensi : nuredys@gmail.com
}

Diterima 27 September 2016 / Disetujui 11 Oktober 2016

\begin{abstract}
ABSTRAK
Penelitian yang bertujuan untuk mendapatkan informasi tentang pemupukan $\mathrm{N}$ dan frekuensi pemangkasan tajuk yang tepat pada tanaman ubi jalar (Ipomoea batatas (L.) Lam.). penelitian dilakukan di Kebun Percobaan Universitas Brawijaya, di Desa Jatikerto, Malang. Rancangan perlakuan yang digunakan adalah Petak Terbagi, dosis pupuk $\mathrm{N}$ ditempatkan pada petak utama, terdiri dari 4 taraf : (1) tanpa dipupuk N, (2) dipupuk $67,5 \mathrm{~kg} \mathrm{~N} \mathrm{ha}^{-1}$, (3) dipupuk $135 \mathrm{~kg} \mathrm{~N} \mathrm{ha}^{-1}$ dan (4) dipupuk 202,5 $\mathrm{kg} \mathrm{N} \mathrm{ha}^{-1}$. Pemangkasan tajuk ditempatkan pada anak petak, terdiri dari 4 macam : (1) tanpa dipangkas, (2) dipangkas 1 kali, (3) dipangkas 2 kali dan (4) dipangkas 3 kali. Pengumpulan data dilakukan secara destruktif meliputi luas daun, masa luas daun, panjang umbi, diameter umbi, bobot umbi per tanaman dan indeks pembagian. Uji $\mathrm{F}$ taraf $5 \%$ digunakan untuk menguji pengaruh perlakuan, sedangkan perbedaan diantara perlakuan didasarkan pada nilai Duncan taraf 5\%. Hasil penelitian menunjukkan terjadi interaksi nyata pada luas daun, masa luas daun dan bobot umbi per tanaman. Luas daun dan masa luas daun tertinggi umumnya didapatkan pada pemupukan $\mathrm{N}$ dosis $202,5 \mathrm{~kg} \mathrm{~N}^{-1}$ dengan tanpa maupun dengan pemangkasan tajuk 1 kali. Bobot umbi per tanaman tertinggi didapatkan pada tanaman yang diberi pupuk $\mathrm{N}$ dengan dosis $135 \mathrm{~kg} \mathrm{~N} \mathrm{ha}^{-1}$ dan pemangkasan tajuk 1 kali.
\end{abstract}

Kata kunci : Aspek agronomis, Hasil, Pemangkasan tajuk, Pemupukan N

\begin{abstract}
The reaserch aimed to get an appropriate $\mathrm{N}$ application and frequency of topping. The experiment conducted in the experimental field of Brawijaya University, Jatikerto village, Malang. The experimental design used Split Plot Design with four levels of $\mathrm{N}\left(0 \mathrm{~kg} \mathrm{~N}\right.$ ha ${ }^{-1} ; 67.5$ $\mathrm{kg} \mathrm{N} \mathrm{ha}{ }^{-1}, 135 \mathrm{~kg} \mathrm{~N} \mathrm{ha}^{-1}$ and $202.5 \mathrm{~kg} \mathrm{~N} \mathrm{ha}^{-1}$ ) as the main plots and four level frequencies of topping (without topping, 1 time, 2 times, and 3 times of topping) as the sub plots with three replications. The data was collected destructively for growth components, yield components and plant growth analysis. $F$ test at $5 \%$ was used to determine the effect of the treatments while the average differences between the treatments referred to Duncan value at $5 \%$. The
\end{abstract}


result showed there were significantly interaction between $\mathrm{N}$ application and frequency of topping on growth components and tuber per plant weight. Combination of $\mathrm{N}$ dosage $202.5 \mathrm{~kg}$ $\mathrm{ha}^{-1}$ and without or once topping showed the largest leaf area and the highest leaf area mass . The highest tuber per plant weight was obtained in $\mathrm{N}$ dosage $135 \mathrm{~kg}$ ha-1 and one time topping.

Keywords : Agronomic aspect, $\mathrm{N}$ application, Sweet potato, Topping

\section{PENDAHULUAN}

Pemanfaatan ubi jalar dalam beberapa tahun terakhir ini telah menunjukkaan peningkatannya secara nyata. Dahulu, ubi jalar hanya dimanfaatkan sebagai makanan sampingan bagi sebagian penduduk yang tinggal di desa. Akan tetapi, seiring dengan meningkatnya teknologi pangan dan industri, menyebabkan kedudukan ubi jalar tidak kalah pentingnya dengan komoditas sumber karbohidrat yang lain. Saat ini, ubi jalar telah dimanfaatkan sebagai bahan baku industri seperti ethanol, gula sirup, alkohol maupun bahan kosmetik yang tidak hanya untuk kalangan sendiri (Indonesia), tetapi juga dalam skala dunia (Tsuno, 1980). Sedangkan di tatanan pangan, ubi jalar telah diproses untuk berbagai jenis makanan seperti kripik, bakpao, es krim, dan jenis makanan lain, selain sebagai cadangan bahan pengganti makanan pokok.

$\mathrm{Hal}$ ini cukup beralasan karena ubi jalar mengandung sejumlah nutrisi yang cukup lengkap seperti karbohidrat yang cukup tinggi, protein, lemak, karoten (pro vitamnin A), vitamin C (setara buah tomat) serta mineral terutama Ca dan Fe. Akibatnya, permintaan ubi jalar terus meningkat. Namun demikian, peningkatan permintaan tersebut tidak diikuti dengan peningkatan luas lahan panen secara proporsional. Oleh karena itu, untuk tetap dapat menjaga kenstabilan dan kontinyuitas produksi ubi jalar, maka pengelolaan tanaman seperti pemupukan $\mathrm{N}$ dan pemangkasan tajuk tanaman sangat diperlukan.

Nitrogen merupakan salah satu unsur hara esensial yang banyak diperlukan oleh tanaman, dan pengaruhnya akan terlihat pada laju pertumbuhan tanaman. Banyak hasil penelitian menunjukkan bahwa peningkatan pemberian $\mathrm{N}$ pada tanaman ubi jalar diikuti dengan perkembangan tajuk yang berlebihan, tetapi tidak diimbangi dengan pembentukan umbi per satuan tanaman. Hasil penelitian Pahlevi dan Suminarti (2015) membuktikan bahwa tanaman ubi jalar yang dipupuk $150 \% \mathrm{~N}$, jumlah daun yang dihasilkan nyata lebih banyak $60 \%$ dibandingkan dengan tanaman yang dipupuk $\mathrm{N}$ sebanyak $50 \%$. Namun demikian, lebih banyaknya jumlah daun yang dihasilkan tersebut berdampak kurang baik terhadap bobot umbi per tanaman yang diperoleh.

Apabila ditinjau berdasarkan bentuk daunnya, tanaman ubi jalar memperlihatkan terjadinya aktifitas fotosintesis yang tinggi per unit luas daun. Sedangkan jika dilihat dari susunan daunnya, menyebabkan rendahnya penetrasi cahaya yang masuk ke dalam tajuk tanaman sebagai akibat terjadinya kondisi saling menaungi antara daun yang satu dengan lainnya. Akibatnya, laju asimilasi bersih berkurang dengan meningkatnya indeks luas daun pada populasi yang ada.

Pemangkasan tajuk pada tanaman ubi jalar dimaksudkan untuk mengendalikan 
pertumbuhan bagian tanaman di atas tanah, selain daun muda hasil pangkasan dapat dikonsumsi sebagai sayuran ataupun pakan ternak (Bartolini, 1982). Namun demikian, besarnya pengaruh pemangkasan tajuk terhadap hasil panenan tergantung pada benyaknya daun yang dipangkas, letak daun pada batang dan periode pertumbuhan tanaman.

\section{BAHAN DAN METODE}

\section{Deskripsi Lokasi Penelitian}

Penelitian dilakukan pada musim penghujan di Kebun Percobaan Akademi Penyuluh Pertanian Negeri Malang, di Desa Tanjung, Kodya Malang. Lokasi terletak pada ketinggian 450 mdpl, jenis tanah Alluvial dan termasuk kedalam tekstur liat berpasir dengan komposisi : liat (41\%) : debu (12\%) : pasir (47\%). Hasil analisis kimia tanah menunjukkan bahwa $\mathrm{pH}$ tanah 6,2, kapasitas tukar kation (KTK) 41,37 me 100 $\mathrm{g}^{-1}$, kejenuhan basa mencapai $54 \%, \mathrm{C}$ organik sebesar $1,69 \%$ dan kandungan $\mathrm{N}$ total tanah sebesar 0,20 (Laboratorium Kimia dan Fisika Tanah, Fakultas Pertanian, Universitas Brawijaya). Secara klimatologis, rata-rata curah hujan bulanan selama penelitian sekitar $197,6 \mathrm{~mm}$, rata-rata suhu harian sekitar $25,08^{\circ} \mathrm{C}$, kelembaban udara sebesar 73,2\%, dan lama penyinaran berkisar antara 5-6 jam per hari (BMKG Karangploso Malang, 2011).

\section{Rancangan Percobaan}

Rancangan perlakuan yang digunakan adalah Petak Terpisah. Dosis pupuk $\mathrm{N}$ ditempatkan pada petak utama, terdiri dari 4 taraf : (1) tanpa dipupuk N, (2) dipupuk N dosis $67,5 \mathrm{~kg} \mathrm{~N} \mathrm{ha}^{-1}$, (3) dipupuk $\mathrm{N}$ dosis 135 $\mathrm{kg} \mathrm{N}^{-1}$ dan (4) dipupuk $\mathrm{N}$ dosis $202,5 \mathrm{~kg} \mathrm{~N}$ $\mathrm{ha}^{-1}$. Sedangkan pemangkasan tajuk ditempatkan pada anak petak, terdiri dari 4 macam : (1) tanpa dipangkas, (2) dipangkas 1 kali umur 35 hari setelah tanam (HST), (3) dipangkas 2 kali umur 35 HST dan 63 HST, dan (4) dipangkas 3 kali umur 35 HST, 63 HST dan 91 HST. Dari kedua faktor tersebut didapatkan 16 kombinasi perlakuan, dan setiap kombinasi perlakuan diulang 3 kali sehingga diperoleh 48 unit kombinasi perlakuan.

\section{Persiapan lahan dan pemetakan}

Pengolahan tanah dilakukan dengan cara dibajak sebanyak 2 kali, bertujuan untuk mendapatkan struktur tanah yang remah. Pembajakan pertama dilakukan 1 bulan sebelum tanam, dan pembajakan kedua, 2 minggu sebelum tanam. Setelah itu, lahan dibagi menjadi 3 blok, masing-masing blok berukuran $335,20 \mathrm{~m}^{2}$, berisi 16 petak perlakuan, dan setiap petak perlakuan berukuran panjang 8,1 $\mathrm{m}$ dan lebar $2 \mathrm{~m}$. Setiap petak perlakuan terdapat 10 guludan, setiap guludan berukuran lebar 60 $\mathrm{cm}$, tinggi $40 \mathrm{~cm}$ dan panjang guludan $2 \mathrm{~m}$. Jarak antar petak perlakuan adalah $0,25 \mathrm{~m}$, dan jarak tanam yang digunakan adalah 25 $\mathrm{cm} \times 90 \mathrm{~cm}$, sehingga dalam 1 hektar terdapat sekitar 44.444 tanaman ubi jalar.

\section{Penanaman dan pemupukan}

Bahan tanam yang digunakan adalah ubi jalar varietas Kretek (lokal Malang), berupa stek batang, panjang $25 \mathrm{~cm}$, berasal dari pertanaman yang telah berumur 2-3 bulan. Sebelum ditanam, bibit diseleksi terlebih dahulu untuk mendapatkan bahan tanam yang sehat dan seragam. Pengurangan daun (50\%) dilakukan sebelum bibit ditanam, bertujuan untuk mengendalikan laju evapotranspirasi. Bibit yang terseleksi kemudian ditanam dengan posisi $60^{\circ}$ dan pada kedalaman $10 \mathrm{~cm}$. Pupuk $\mathrm{P}$ dan $\mathrm{K}$ 
diaplikasikan pada saat tanam seluruh dosis, masing-masing sebanyak $60 \mathrm{~kg} \mathrm{P}_{2} \mathrm{O}_{5} \mathrm{ha}^{-1}$ dan $60 \mathrm{Kg} \mathrm{K} \mathrm{K}_{2} \mathrm{O} \mathrm{ha}^{-1}$. Sedangkan pupuk $\mathrm{N}$ diberikan secara bertahap, $1 / 3$ bagian diaplikasikan pada saat tanaman berumur 7 HST, dan sisanya (2/3 bagian) diaplikasikan ketika tanaman berumur 42 HST dengan dosis sesuai perlakuan. Pupuk diaplikasikan dengan cara ditugal $10 \mathrm{~cm}$ di sisi tanaman dengan kedalaman $10 \mathrm{~cm}$.

\section{Pengumpulan data}

Pengumpulan data dilakukan secara destruktif dengan cara mengambil 3 tanaman contoh untuk setiap kombinasi perlakuan, dilakukan pada saat tanaman berumur $40 \mathrm{HST}, 55 \mathrm{HST}, 70 \mathrm{HST}, 85 \mathrm{HST}$, 100 HST, 115 HST dan saat panen (120 HST), meliputi aspek agronomis, yaitu luas daun dan masa luas daun. Sedangkan komponen hasil meliputi pengukuran panjang umbi, diameter umbi dan bobot umbi per tanaman. Analisis pertumbuhan tanaman mencakup pengukuran indeks pembagian.

Aspek Agronomis (Sitompul dan Guritno, 1995)

Luas daun, dihitung untuk daun yang telah membuka penuh dan masih berwarna hijau, dengan menggunakan alat "Leaf Area meter" tipe $\mathrm{LI} 3100 \mathrm{C}$.

Masa luas daun (MLD), dihitung dengan menggunakan rumus :

$$
\mathrm{MLD}=\frac{(\mathrm{ILD} 1+\mathrm{ILD} 2)(\mathrm{L2}-\mathrm{t1})}{2}
$$

\section{Pengukuran komponen hasil}

Panjang umbi, diukur dari pangkal hingga ujung umbi dengan menggunakan rol meter.

Diameter umbi. Pengukuran diameter umbi dilakukan pada bagian pangkal, tengah dan ujung dari umbi kemudian dirata-ratakan, dengan menggunakan jangka sorong.

Bobot umbi per tanaman, ditimbang seluruh umbi yang terbentuk dengan menggunakan timbangan analitik.

Analisis pertumbuhan tanaman (Evans, 1972)

Indeks pembagian (IP), menggambarkan banyaknya asimilat yang dialokasikan ke bagian umbi dari total asimilat yang dihasilkan, dihitung dengan menggunakan rumus:

$$
\mathrm{IP}=\frac{\text { Hasil ekonomis (umbi) }}{\text { Bobot kering total tanaman }}
$$

Analisis Statistika (Gomez dan Gomez, 1983)

Model dasar analisis statistik yang digunakan adalah : Yijk $=\mu+\alpha i+\beta j+p k+($ $\alpha \beta) i j+\sum i j k$

Dimana :

Yijk : pengamatan untuk pupuk $\mathrm{N}$ level ke i, pemangkasan tajuk level ke j dan pada kelompok ke $\mathrm{k}$

$\mu \quad$ : nilai tengah umum

ai : pengaruh pupuk $\mathrm{N}$ pada level ke i

$\beta \mathrm{j} \quad$ : pengaruh pemangkasan tajuk pada level ke j

Pk : pengaruh kelompok ke $\mathrm{k}$

$(\alpha \beta)$ ij : pengaruh interaksi pupuk $\mathrm{N}$ dan pemangkasan tajuk pada level ke i dan ke j

$\sum \mathrm{ijk} \quad$ : galat percobaan untuk pengamatan ke i, j, dan k 
HASIL

Interaksi nyata antara pemupukan $\mathrm{N}$ dan pemangkasan tajuk terjadi pada luas daun, masa luas daun dan bobot umbi per tanaman. Sedangkan panjang umbi, diameter umbi dan indeks panen hanya dipengaruhi oleh masing-masing faktornya.

\section{Aspek agronomis}

\section{Luas Daun}

Pada Tabel 1 disajikan rerata luas daun akibat terjadinya interaksi nyata antara pemupukan $\mathrm{N}$ dan frekuensi pemangkasan tajuk pada saat tanaman berumur 100 hari setelah tanam (HST).

Tabel 1. Rerata luas daun $\left(\mathrm{cm}^{2}\right)$ pada empat dosis pemupukan $\mathrm{N}$ dan empat frekuensi pemangkasan tajuk pada saat tanaman berumur 100 HST

\begin{tabular}{lccrc}
\hline \multirow{2}{*}{ Perlakuan } & \multicolumn{5}{c}{ Frekuensi pemangkasan tajuk (kali) } \\
\cline { 2 - 5 } & 0 & 1 & 2 & 3 \\
\hline Dosis N $\left(\mathrm{kg} \mathrm{ha}^{-1}\right)$ & & & & \\
0 & $3805,60 \mathrm{ef}$ & $1970,60 \mathrm{c}$ & $855,00 \mathrm{ab}$ & $408,00 \mathrm{a}$ \\
67,5 & $6460,67 \mathrm{~g}$ & $2755,00 \mathrm{~d}$ & $1007,63 \mathrm{~b}$ & $544,99 \mathrm{ab}$ \\
135,0 & $8323,70 \mathrm{~h}$ & $3455,91 \mathrm{e}$ & $1293,33 \mathrm{~b}$ & $647,67 \mathrm{ab}$ \\
202,5 & $8834,08 \mathrm{i}$ & $4075,72 \mathrm{f}$ & $1463,05 \mathrm{~b}$ & $737,33 \mathrm{ab}$ \\
\hline
\end{tabular}

Keterangan : Bilangan yang didampingi huruf yang sama pada kolom yang sama maupun pada baris yang sama, tidak berbeda nyata pada $p=0,05$ berdasarkan uji Duncan

Tabel 1 menunjukkan bahwa pada setiap level pemupukan $\mathrm{N}$, daun terluas didapatkan pada tanaman yang tanpa dipangkas, dan memperlihatkan terjadinya pengurangan luas daun dengan semakin ditingkatkannya frekuensi pemangkasan tajuk.

Pemangkasan tajuk yang dilakukan hingga tiga kali, pengurangan luas daun adalah paling tinggi, dan semakin berkurang dengan diturunkannya frekuensi pemangkasan dari 3 kali hingga menjadi tanpa pemangkasan. Sedangkan apabila ditinjau berdasarkan pengaruh frekuensi pemangkasan tajuk pada berbagai level pemupukan $\mathrm{N}$, maka untuk perlakuan tanpa pemangkasan maupun 1 kali pemangkasan tajuk, daun terluas umumnya didapatkan pada tanaman yang dipupuk $\mathrm{N}$ sebanyak $202,5 \mathrm{~kg} \mathrm{ha}^{-1}$.

Pengurangan setiap level pemupukan $\mathrm{N}$ dari $202,5 \mathrm{~kg} \mathrm{~N}^{-1}$ menjadi $135,0 \mathrm{~kg} \mathrm{~N} \mathrm{ha}^{-1}$; dari $135,0 \mathrm{~kg} \mathrm{~N}^{-1}$ menjadi $67,5 \mathrm{~kg} \mathrm{~N}^{-1}$ serta dari $67,5 \mathrm{~kg} \mathrm{~N}^{-1}$ menjadi tanpa pemupukan $\mathrm{N}$, mengakibatkan berkurangnya luas daun masing-masing sebesar 510 $\mathrm{cm}^{2}(5,78 \%) ; 1.863,03 \mathrm{~cm}^{2}$ (22,38\%) dan $2.655,07 \mathrm{~cm}^{2}(41,10 \%)$ untuk perlakuan tanpa pe-mangkasan tajuk, dan sebesar $619,81 \mathrm{~cm}^{2}$ (15,21\%); 700,91 $\mathrm{cm}^{2}$ (20,28\%) dan 784,4 $\mathrm{cm}^{2} \quad(28,47 \%) \quad$ untuk pemangkasan tajuk 1 kali. Akan tetapi untuk perlakuan pemangkasan tajuk 2 dan 3 kali, luas daun yang dihasilkan pada berbagai level pemupukan $\mathrm{N}$ adalah tidak berbeda nyata.

\section{Masa luas daun}

Masa luas daun merupakan parameter yang dipergunakan untuk mengetahui lama daun berada pada tanaman. Pada Tabel 2 disajikan rerata masa luas daun akibat terjadinya interaksi nyata antara pemupukan $\mathrm{N}$ dan frekuensi pemangkasan tajuk pada saat tanaman berumur 100 HST. 
Tabel 2. Rerata masa daun (hari) pada empat dosis pemupukan $\mathrm{N}$ dan empat frekuensi pemangkasan tajuk pada saat tanaman berumur 100 HST

\begin{tabular}{lcccc}
\hline \multirow{2}{*}{ Perlakuan } & \multicolumn{4}{c}{ Frekuensi pemangkasan tajuk (kali) } \\
\cline { 2 - 5 } & 0 & 1 & 2 & 3 \\
\hline Dosis N $\left(\mathrm{kg} \mathrm{ha}^{-1}\right)$ & & & & \\
0 & $14,34 \mathrm{~h}$ & $7,08 \mathrm{~d}$ & $2,73 \mathrm{ab}$ & $2,04 \mathrm{a}$ \\
67,5 & $21,69 \mathrm{i}$ & $9,19 \mathrm{e}$ & $3,52 \mathrm{~b}$ & $2,80 \mathrm{ab}$ \\
135,0 & $27,50 \mathrm{j}$ & $11,49 \mathrm{f}$ & $4,39 \mathrm{bc}$ & $3,38 \mathrm{~b}$ \\
202,5 & $30,91 \mathrm{k}$ & $13,22 \mathrm{~g}$ & $5,03 \mathrm{c}$ & $3,90 \mathrm{bc}$ \\
\hline
\end{tabular}

Keterangan : Bilangan yang didampingi huruf yang sama pada kolom yang sama maupun pada baris yang sama, tidak berbeda nyata pada $\mathrm{p}=0,05$ berdasarkan uji Duncan

Tabel 2 menunjukkan bahwa pada berbagai level pemupukan $\mathrm{N}$, masa luas daun terpanjang didapatkan pada perlakuan tanpa pemangkasan, dan memperlihatkan terjadinya pengurangan ketika frekuensi pemangkasan tajuk ditingkatkan dari tanpa pemangkasan hingga menjadi 3 kali pemangkasan. Rata-rata pengurangan masa luas daun tertinggi terjadi ketika frekuensi pemangkasan tajuk diubah dari satu kali pemangkasan menjadi 2 kali pemangkasan (61,72\%), kemudian diikuti dengan perubahan frekuensi pemangkasan dari tanpa dipangkas menjadi dipangkas 1 kali (55,93\%), dan yang paling rendah terjadi ketika frekuensi pemangkasan tajuk 2 kali diubah menjadi 3 kali (22,8\%).

Frekuensi pemangkasan tajuk mempunyai pengaruh yang berbeda pada level pemupukan $\mathrm{N}$ yang berbeda. Pada perlakuan tanpa frekuensi pemangkasan maupun 1 kali pemangkasan tajuk, masa luas daun terpanjang didapatkan pada tingkat pemupukan 202, $5 \mathrm{~kg} N \mathrm{ha}^{-1}$, dan memperlihatkan terjadinya pengurangan masa luas daun dengan diturunkannya dosis pemupukan N dari 202,5 $\mathrm{kg} \mathrm{ha}^{-1}$ hingga menjadi tanpa pemupukan N. Pengurangan tertinggi masa luas terjadi ketika dosis pemupukan $\mathrm{N}$ diturunkan dari $67,5 \mathrm{~kg} \mathrm{~N}^{-1}$ menjadi tanpa pemupukan $\mathrm{N}$, masing-masing sebesar 33,89\% untuk perlakuan tanpa pemangkasan dan sebesar 22,96\% untuk perlakuan 1 kali pemangkasan. Akan tetapi, ketika tanaman dipangkas 2 kali, masa luas daun yang dihasilkan pada tingkat pemupukan 0 hingga $135 \mathrm{~kg} \mathrm{~N}^{-1}$ adalah tidak berbeda nyata, walaupun masa luas daun yang dihasilkan pada tingkat pemupukan 0 dan $67,5 \mathrm{~kg} \mathrm{~N}^{-1}$ tersebut masih lebih pendek $45,73 \%$ dan 30,02\% jika dibandingkan dengan aplikasi $\mathrm{N}$ pada level pemupukan $202,5 \mathrm{~kg} \mathrm{ha}^{-1}$. Masa luas daun memperlihatkan hasil yang tidak berbeda nyata pada tingkat pemupukan N 135 dan $202,5 \mathrm{~kg} \mathrm{ha}^{-1}$.

\section{Komponen hasil}

1. Panjang umbi dan diameter umbi

Pengaruh pemupukan $\mathrm{N}$ dan frekuensi pemangkasan tajuk terhadap panjang dan diameter umbi disajikan pada Tabel 3. 
Tabel 3. Rerata panjang dan diameter umbi pada empat dosis pemupukan $\mathrm{N}$ dan empat frekuensi pemangkasan tajuk pada saat panen

\begin{tabular}{lcc}
\hline \multirow{2}{*}{ Perlakuan } & Panjang umbi & Diameter umbi \\
\cline { 2 - 3 } & & $--\mathrm{cm}--$ \\
\hline Dosis N $\left(\mathrm{kg} \mathrm{ha}^{-1}\right)$ & $7,45 \mathrm{a}$ & \\
0 & $8,83 \mathrm{a}$ & $5,90 \mathrm{a}$ \\
67,5 & $15,11 \mathrm{c}$ & $5,01 \mathrm{a}$ \\
135,0 & $12,10 \mathrm{~b}$ & $6,81 \mathrm{~b}$ \\
202,5 & & $5,37 \mathrm{a}$ \\
Duncan 5\% & & \\
\hline Frekuensi pemangkasan tajuk (kali) & $12,83 \mathrm{~b}$ & 5,50 \\
\hline 0 & $16,07 \mathrm{c}$ & 6,02 \\
1 & $8,59 \mathrm{a}$ & 5,26 \\
2 & $7,83 \mathrm{a}$ & 5,16 \\
3 & & th \\
\hline
\end{tabular}

Keterangan : Bilangan yang didampingi huruf yang sama pada kolom yang sama maupun pada baris yang sama, tidak berbeda nyata pada $\mathrm{p}=0,05$ berdasarkan uji Duncan ; tn : tidak berbeda nyata

Tabel 3 menunjukkan bahwa umbi terpanjang didapatkan pada pemupukan $\mathrm{N}$ dosis $135 \mathrm{~kg} \mathrm{ha-1}$, dan memperlihatkan terjadinya pengurangan panjang umbi sekitar $7,66 \mathrm{~cm}$ (102,82\%) dan sekitar 6,28 cm (71,12\%) ketika pupuk $\mathrm{N}$ yang diaplikasikan diturunkan dosisnya, yaitu dari $135 \mathrm{~kg} \mathrm{ha}^{-1}$ menjadi $67,5 \mathrm{~kg} \mathrm{ha}^{-1}$ dan menjadi tanpa dipupuk. Pengurangan panjang umbi sekitar $3,01 \mathrm{~cm}(24,88 \%)$ juga terjadi ketika dosis pupuk $\mathrm{N}$ ditingkatkan dari $135 \mathrm{~kg} \mathrm{ha}^{-1}$ menjadi $202,5 \mathrm{~kg} \mathrm{ha}^{-1}$. Panjang umbi yang dihasilkan pada perlakuan tanpa pupuk maupun yang dipupuk $\mathrm{N}$ sebanyak $65,5 \mathrm{~kg} \mathrm{ha}^{-1}$ adalah tidak berbeda nyata.

Umbi terpanjang pada perlakuan frekuensi pemangkasan tajuk didapatkan pada perlakuan 1 kali pemangkasan. Peningkatan frekuensi pemangkasan dari satu kali menjadi 2 dan 3 kali mengakibatkan berkurangnya panjang umbi masing-masing sepanjang 7,48 cm (87,08\%) dan sekitar 8,24 cm $(105,24 \%)$. Hal yang demikian juga terjadi ketika frekuensi pemangkasan diubah dari 1 kali menjadi tanpa dipangkas, walaupun panjang umbi yang dihasilkan pada perlakuan tanpa pemangkasan tersebut masih lebih panjang 4,24 cm (49,36\%) dan sekitar $5 \mathrm{~cm}$ $(63,86 \%)$ dibandingkan dengan pemangkasan tajuk 2 dan 3 kali. Pemangkasan tajuk 2 dan 3 kali menghasilkan panjang umbi yang tidak berbeda nyata.

Diameter umbi hanya dipengaruhi oleh tingkat pemupukan $\mathrm{N}$, dan diameter yang paling lebar didapatkan pada pemupukan $\mathrm{N}$ dosis $135 \mathrm{~kg} \mathrm{ha}^{-1}$. Penurunan diameter umbi terjadi dengan diturunkannya dosis pemupukan $\mathrm{N}$ dari $135 \mathrm{~kg} \mathrm{ha}^{-1}$ menjadi tanpa dipupuk maupun menjadi $67,5 \mathrm{~kg} \mathrm{ha}^{-1}$. Hal yang demikian juga terjaadi ketika dosis pemupukan $\mathrm{N}$ ditingkatkan dari $135 \mathrm{~kg} \mathrm{ha}{ }^{-1}$ menjadi 202,5 $\mathrm{kg} \mathrm{N} \mathrm{ha}^{-1}$. 


\section{Bobot umbi per tanaman}

Pada Tabel 4 disajikan rerata bobot umbi per tanamsan akibat terjadinya interaksi nyata antara pemupukan $\mathrm{N}$ dan frekuensi pemangkasan tajuk.

Pada perlakuan tanpa pemupukan $\mathrm{N}$, bobot umbi per tanaman paling berat didapatkan pada frekuensi pemangkasan 1 kali. Peningkatan frekuensi pemangkasan dari satu kali menjadi 2 dan 3 kali mengakibatkan berkurangnya bobot umbi masing-masing sebesar 51,13 g (78,82\%) dan 82,49 g $(162,77 \%)$.

Tabel 4. Rerata bobot umbi per tanaman pada empat dosis pemupukan $\mathrm{N}$ dan empat frekuensi pemangkasan tajuk pada saat tanaman panen

\begin{tabular}{|c|c|c|c|c|}
\hline \multirow{2}{*}{ Perlakuan } & \multicolumn{4}{|c|}{ Frekuensi pemangkasan tajuk (kali) } \\
\hline & 0 & 1 & 2 & 3 \\
\hline \multicolumn{5}{|c|}{ Dosis N $\left(\mathrm{kg} \mathrm{ha}^{-1}\right)$} \\
\hline 0 & $85,74 \mathrm{bc}$ & 133,17 def & $64,87 b$ & 50,68 a \\
\hline 67,5 & $100,48 \mathrm{bcd}$ & $165,24 \mathrm{fg}$ & $98,54 \mathrm{bcd}$ & $66,90 \mathrm{~b}$ \\
\hline 135,0 & 138,40 ef & $298,54 \mathrm{~h}$ & 101,55 bcde & $92,82 \mathrm{bc}$ \\
\hline 202,5 & 109,72 cde & $188,50 \mathrm{~g}$ & 92,82 bc & $85,15 \mathrm{bc}$ \\
\hline
\end{tabular}

Keterangan : Bilangan yang didampingi huruf yang sama pada kolom yang sama maupun pada baris yang sama, tidak berbeda nyata pada $p=0,05$ berdasarkan uji Duncan

Pengurangan bobot umbi juga terjadi ketika frekuensi pemangkasan diubah dari 1 kali menjadi tanpa dipangkas, maupun dari 1 kali menjadi tanpa dipangkas, maupun dari yang tanpa dipangkas menjadi 3 kali pemangkasan. Pemangkasan 2 kali menghasilkan bobot umbi yang tidak berbeda nyata dengan perlakuan tanpa dipangkas. Sedangkan pada pemupukan $\mathrm{N}$ dosis $67,5 \mathrm{~kg}$ $\mathrm{ha}^{-1}$, bobot umbi paling tinggi juga didapatkan pada pemangkasan 1 kali. Pemangkasan 2 hingga 3 kali, bobot umbi yang dihasilkan tidak berbeda nyata dengan perlakuan tanpa pemangkasan. Namun demikian, ketiga hasil tersebut lebih rendah $66,7 \mathrm{~g}(67,69 \%)$ dan 98,34 g (146,99\%) serta 64,76 g (64,45\%) jika dibandingkan dengan pemangkasan 1 kali.

Pola hasil yang demikian juga diperlihatkan pada pemupukan $\mathrm{N}$ dosis $202,5 \mathrm{~kg} \mathrm{ha}^{-1}$. Akan tetapi untuk pemupukan $\mathrm{N}$ dosis $135 \mathrm{~kg}$ ha-1, pemangkasan 2 dan 3 kali menghasilkan bobot umbi yang tidak berbeda nyata, dan lebih rendah 196,99 g (193,98\%) dan 205,72 g (221,63\%) jika dibandingkan dengan pemangkasan 1 kali, walaupun bobot umbi yang dihasilkan pada frekuensi pemangkasan 2 kali tidak berbeda nyata dengan perlakuan tanpa pemangkasan. Bobot umbi paling tinggi didapatkan pada pemangkasan 1 kali. Pengubahan frekuensi pemangkasan dari 1 kali menjadi tanpa pemangkasan juga menyebabkan berkurangnya bobot umbi sebesar 160, $14 \mathrm{~g}$ (115,71\%).

Bervariasinya frekuensi pemangkasan tajuk juga mempunyai pengaruh pada berbagai pemupukan $\mathrm{N}$ yang diaplikasikan. Pada perlakuan tanpa pemangkasan, bobot umbi memperlihatkan hasil yang tidak berbeda nyata antara pemupukan $\mathrm{N}$ dosis 135 $\mathrm{kg} \mathrm{ha}{ }^{-1}$ dengan 202,5 kg ha- Namun 
demikian, pada pemupukan $\mathrm{N}$ dosis $135 \mathrm{~kg}$ $\mathrm{ha}^{-1}$ tersebut, bobot umbi yang dihasilkan nyata lebih berat $37,92 \mathrm{~g} \quad(37,74 \%)$ dan $52,66 \mathrm{~g}(61,42 \%)$ jika dibandingkan dengan pemupukan $\mathrm{N}$ dosis $67,5 \mathrm{~kg} \mathrm{ha}^{-1}$ dan tanpa pemupukan. Walaupun bobot umbi yang dihasilkan pada perlakuan tanpa pemupukan maupun yang dipupuk $\mathrm{N}$ dosis $67,5 \mathrm{~kg} \mathrm{ha}^{-1}$ dan $202,5 \mathrm{~kg} \mathrm{ha}^{-1}$ adalah tidak berbeda nyata.

\section{Analisis Pertumbuhan Tanaman}

\section{Indeks Pembagian (IP)}

Indeks pembagian menggambarkan seberapa banyak asimilat yang dialokasikan ke bagian ekonomis dari asimilat total yang dihasilkan. Pada Tabel 5 disajikan rerata nilai Indeks pembagian akibat pemupukan $\mathrm{N}$ dan frekuensi pemangkasan tajuk.

Tabel 5 menunjukkan bahwa pemupukan $\mathrm{N}$ dosis $135 \mathrm{~kg} \mathrm{ha}^{-1}$ menghasilkan indeks pembagian lebih tinggi $13,89 \%$ jika dibandingkan dengan tanpa pemupukan $\mathrm{N}$. Namun demikian, nilai indeks panen yang dihasilkan pada perlakuan tanpa pemupukan tersebut, tidak berbeda nyata dengan perlakuan pemupukan $\mathrm{N}$ dosis $67,5 \mathrm{~kg} \mathrm{ha}^{-1}$ dan $202,5 \mathrm{~kg} \mathrm{ha}^{-1}$. Hal yang demikian juga berlaku pada pemupukan $\mathrm{N}$ dosis $67,5 \mathrm{~kg} \mathrm{ha}^{-1}$ hingga $202,5 \mathrm{~kg} \mathrm{ha}^{-1}$.

Sedangkan pada perlakuan frekuensi pemangkasan, indeks pembagian yang lebih tinggi didapatkan pada perlakuan tanpa pemangkasan maupun yang tajuknya dipangkas 1 kali, jika dibandingkan dengan pemangkasan tajuk 3 kali. Akan tetapi, untuk perlakuan tanpa pemangkasan maupun yang dipangkas 1 kali, indeks panen yang dihasilkan tidak berbeda nyata dengan pemangkasan tajuk 2 kali. Demikian juga untuk pemangkasan tajuk 2 dan 3 kali.
Tabel 5. Rerata indeks pembagian pada empat dosis pemupukan $\mathrm{N}$ dan empat frekuensi pemangkasan tajuk pada saat panen

\begin{tabular}{ll}
\hline \multicolumn{1}{c}{ Perlakuan } & Indeks Pembagian \\
\hline Dosis N $\left(\mathrm{kg} \mathrm{ha}^{-1}\right)$ & $0,78 \mathrm{a}$ \\
0 & $0,82 \mathrm{ab}$ \\
67,5 & $0,84 \mathrm{~b}$ \\
135,0 & $0,82 \mathrm{ab}$ \\
202,5 & \\
Duncan 5\% & \\
\hline Frekuensi pemangkasan tajuk & \\
0 & $0,83 \mathrm{~b}$ \\
1 & $0,86 \mathrm{~b}$ \\
2 & $0,80 \mathrm{ab}$ \\
3 & $0,78 \mathrm{a}$ \\
Duncan 5\% & \\
\hline
\end{tabular}

Keterangan : Bilangan yang didampingi huruf yang sama pada kolom yang sama maupun pada baris yang sama, tidak berbeda nyata pada $p=0,05$ berdasarkan uji Duncan; tn : tidak berbeda nyata

\section{PEMBAHASAN}

Pengelolaan tanaman menjadi penting dalam budidaya tanaman dalam upaya untuk mendapatkan hasil yang tinggi secara kuantitas maupun kualitas. Hal ini sangat terkait bahwa untuk mendapatkan hasil yang tinggi pada tanaman ubi jalar, pemupukan $\mathrm{N}$ sangat diperlukan. Namun demikian, dengan pemberian $\mathrm{N}$ yang tinggi pada tanaman ubi jalar akan selalu diikuti oleh perkembangan tajuk yang berlebihan. Oleh karena itu untuk mengendalikan laju pertumbuhan bagian atas tanah (shoot), maka pemangkasan tajuk perlu dilakukan. 
Hasil penelitian menunjukkan bahwa terjadi interaksi nyata antara pemupukan $\mathrm{N}$ dan frekuensi pemangkasan tajuk pada parameter luas daun, masa luas daun, dan bobot umbi per tanaman. Pada parameter luas daun, pemberian berbagai level pupuk $\mathrm{N}$, daun terluas didapatkan pada perlakuan tanpa pemangkasan tajuk. Hal ini cukup relevan karena dengan tanpa pemangkasan tajuk, jumlah daun yang dapat dihasilkan adalah paling banyak. Akan tetapi, ketika tanaman mengalami pemangkasan tajuk, jumlah daun yang dihasilkan berkurang, dan berkurangnya jumlah daun ini akan memberi kontribusi terhadap luas daun yang dihasilkan (rendah) (Bartolini, 1982).

Hasil analisis regresi membuktikan terbentuknya hubungan linier antara frekuensi pemangkasan tajuk dengan jumlah daun maupun luas daun yang diberikan melalui persamaan $Y=-86,03 X+36,5 ; R^{2}=$ 0,94 (untuk jumlah daun) dan $Y=-2072,4 X+$ $8095,9\left(R^{2}=0,90\right)$ untuk luas daun. Persamaan tersebut memberi arti bahwa dengan semakin seringnya tajuk dipangkas, maka luas daun yang dihasilkan juga semakin sempit. Sedangkan apabila dilihat dari pengaruh frekuensi pemangkasan tajuk pada berbagai level pemupukan $\mathrm{N}$, maka pada perlakuan tanpa pemangkasan maupun yang dipangkas 1 kali, daun terluas didapatkan pada aplikasi $\mathrm{N}$ sebanyak $202,5 \mathrm{~kg} \mathrm{ha}^{-1}$, dan menunjukkan terjadinya pengurangan luas daun dengan diturunkannya dosis pemupukan $\mathrm{N}$ dari $202,5 \mathrm{~kg} \mathrm{ha}^{-1}$ hingga menjadi tanpa pemupukan.

Lebih luasnya daun yang dihasilkan pada kombinasi tersebut adalah sebagai akibat lebih sedikitnya frekuensi pemangkasan, selain $\mathrm{N}$ yang diaplikasikan cukup untuk memenuhi pertumbuhan tanaman. Daun merupakan tempat berlangsungnya kegiatan fotosintesis tanaman, oleh karena itu dengan semakin luasnya permukaan daun, maka kapasitas tanaman untuk melakukan fotosintesis juga tinggi. Akibatnya asimilat yang dihasilkan menjadi banyak. Hal ini didukung pula dengan tingginya tingkat ketersediaan $\mathrm{N}$ bagi tanaman yang berfungsi untuk pembentukan klorofil.

Hasil penelitian Purnamaningsih et al. (2009) menginformasikan bahwa tanaman talas yang dipupuk $\mathrm{N}$ sebanyak $150 \%$, kandungan klorofil a yang dihasilkan sebesar 2209,91 $\mathrm{\mu g} / 2 \mathrm{~g}$ bs dan klorofil b sebesar $609,93 \mu \mathrm{g} / 2 \mathrm{~g}$ bs, dan kandungan ini nyata lebih tinggi $45,87 \%$ dan $59,75 \%$ jika dibandingkan dengan tanaman yang dipupuk $\mathrm{N}$ dosis 50\%, masing-masing sebesar 1515,0 $\mu \mathrm{g} / 2 \mathrm{~g}$ bs untuk klorofi a dan sebesar 381,80 $\mu \mathrm{g} / 2 \mathrm{~g}$ bs untuk klorofil b. klorofil a $\left(\mathrm{C}_{55} \mathrm{H}_{72} \mathrm{O}_{5} \mathrm{~N}_{4} \mathrm{Mg}\right)$, berperan dalam penyerapan dan pengumpulan cahaya, sedangkan klorofil b $\left(\mathrm{C}_{55} \mathrm{H}_{70} \mathrm{O}_{6} \mathrm{~N}_{4} \mathrm{Mg}\right)$ berfungsi untuk mengubah energi cahaya menjadi energi kimia, atau yang umum disebut sebagai pusat reaksi (P700).

Apabila kandungan klorofil cukup tinggi pada tanaman, maka akan diikuti dengan laju fotosintesis yang tinggi sehingga asimilat yang dihasilkan juga banyak. Asimilat adalah energi, dan sebagian energi yang berasal dari asimilat tersebut akan digunakan untuk energi pertumbuhan seperti dalam pembentukan jumlah daun, perkembangan luas daun ataupun organ tanaman yang lain (Alam et al., 2010). Oleh karena itu, apabila tingkat ketersediaan $\mathrm{N}$ tanaman rendah, apalagi diiukti dengan tingginya tingkat frekuensi pemangkasan, maka asimilat yang 
dihasilkan akan rendah, dan selanjutnya akan berdampak pada rendahnya kemampuan tanaman untuk tumbuh dan berkembang.

Masa luas daun menurut Sitompul (2016) menggambarkan lamanya daun tinggal pada tanaman, sehingga semakin lama daun tinggal pada tanaman, maka semakin banyak pula asimilat yang dapat dihasilkan. Hasil penelitian menunjukkan bahwa pada berbagai level pemupukan $\mathrm{N}$, masa luas daun paling lama didapatkan pada perlakuan tanpa pemangkasan, sedangkan masa luas daun yang lebih pendek didapatkan pada pemangkasan 2 dan 3 kali. Hal ini cukup dimengerti karena dengan semakin seringnya pemangkasan itu dilakukan, maka daun tidak akan lebih lama tinggal pada tanaman, sehingga kapasitas tanaman untuk menghasilkan asimilat juga rendah.

Bobot umbi menggambarkan kemampuan suatu tanaman dalam mentranslokasikan asimilat ke bagian organ penyimpan dari asimilat total yang diperoleh. Pada penelitian ini, bobot umbi per tanaman paling tinggi didapatkan pada pemupukan $\mathrm{N}$ dosis $135 \mathrm{~kg}$ ha $^{-1}$ yang diikuti dengan 1 kali pemangkasan. $\mathrm{Hal}$ ini cukup beralasan karena aplikasi $\mathrm{N}$ yang tinggi $\left(202,5 \mathrm{~kg} \mathrm{~N}^{-1}\right)$ pada tanaman ubi jalar hanya akan berdampak pada meningkatnya laju perkembangan organ tanaman di atas permukaan tanah seperti jumlah dan luas daun (Tabel 1). Meningkatnya jumlah daun maupun luas daun tersebut tidak sebanding dengan umbi yang dihasilkan sebagai akibat menurunnya laju asimilasi bersih tanaman, sehingga produksi bahan kering yang dihasilkan juga berkurang (Ranjha et al., 2016). Oleh karena itu untuk mendapatkan hasil yang tinggi dan dalam upaya untuk menjaga keseimbangan agronomik yang baik antara organ di atas permukaan tanah dan di bawah permukaan tanah, maka diperlukan pemupukan $\mathrm{N}$ yang tepat pada tanaman. Hasil analisis regresi membuktikan terbentuknya hubungan kuadratik antara pemupukan $N(X)$ dengan bobot umbi $(Y)$ sebagaimana disajikan pada Gambar 1.



Gambar 1. Bentuk hubungan antara pemupukan $\mathrm{N}$ dengan bobot umbi per tanaman

Berdasar pada persamaan tersebut di atas maka dapat diketahui $\mathrm{N}$ optimum yang diperlukan tanaman ubi jalar yaitu sebesar 142,86 kg N ha ${ }^{-1}$ atau setara dengan 317, 46 $\mathrm{kg}$ urea $\mathrm{ha}^{-1}$. Hal ini berarti bahwa penambahan pupuk $\mathrm{N}$ di atas nilai optimum akan dapat menurunkan hasil. Hal yang demikian juga didapatkan pada perlakuan pemangkasan tajuk. Pada pemangkasan tajuk 1 kali yang dilakukan pada saat tanaman berumur 35 HST, bobot umbi yang dihasilkan paling tinggi dibandingkan dengan tanaman yang tanpa dipangkas maupun yang tajuknya dipangkas 2 hingga 3 kali.

Pada tanaman yang tidak dipangkas, kurang terjadinya keseimbangan agronomik antara bagian organ di atas permukaan tanah 
dengan bagian organ di bawah permukaan tanah. Sedangkan rendahnya bobot umbi yang dihasilkan pada tanaman yang dipangkas 2 dan 3 kali adalah sebagai akibat : (1) pemangkasan tajuk yang ke 2 dilakukan pada saat tanaman berumur 61 HST, sedangkan pemangkasan tajuk yang ke 3 dilakukan ketika tanaman berumur 91 HST. Pada kondisi ini tanaman telah memasuki fase pengisian dan perkembangan umbi. Oleh karena itu, apa-bila tanaman dipangkas tajuknya hingga umur tersebut, maka asimilat yang telah tersimpan sebagai umbi dirombak kembali menjadi energi untuk pertumbuhan. Sementara besar pangkasan adalah 50\% dari panjang sulur. (2) Akibat adanya kegiatan pemangkasan, apalagi hingga 2 dan 3 kali, menyebabkan daun yang tertinggal adalah daun-daun tua yang bersifat kurang produktif yang kemampuan untuk melakukan fotosintesisnya telah berkurang (Bartolini, 1982). Akibatnya asimilat yang dihasilkan juga rendah, sehingga bobot umbi yang dihasilkan juga rendah. Hasil analisis regresi juga menunjukkan terjadinya tanggapan kuadratik antara frekuensi pemangkasan tajuk (X) dengan bobot umbi per tanaman (Y) yang diberikan melalui suatu persamaan : $Y=-10,86 X^{2}+65,26 X+26,85 ; R^{2}=0,90$ *

Tinggi rendahnya bobot umbi juga sangat dipengaruhi oleh tinggi rendahnya nilai indeks pembagian, yang menurut Sitompul (2016), bahwa tanaman dengan IP tinggi (lebih dari $0,5)$, hasil ekonomis yang diperoleh juga akan tinggi. Tabel 5 menunjukkan bahwa nilai IP yang lebih tinggi didapatkan pada tanaman yang dipupuk $\mathrm{N}$ dosis $135 \mathrm{~kg} \mathrm{ha}^{-1}$, dan secara terpisah bahwa nilai IP yang lebih tinggi juga didapatkan pada tanaman yang dipangkas 1 kali. Selain itu, tingginya bobot umbi tersebut juga sebagai akibat lebih tingginya nilai komponen hasil seperti panjang dan diameter umbi. Alam et al. (2010) menyatakan bahwa hasil akhir suatu tanaman merupakan fungsi dari komponen hasillnya, dan ini telah dibuktikan dengan hasil penelitian ini. Hasil analisis regresi membuktikan terbentuknya hubungan linier antara panjang umbi $(X)$ dengan bobot umbi (Y) (Gambar 2).



Gambar 2. Bentuk dan pola hubungan antara panjang umbi dengan bobot umbi

Persamaan tersebut member arti bahwa dengan semakin panjang umbi yang dihasilkan, maka semakin berat pula bobot umbi yang diperoleh. Hal yang demikian juga berlaku pada diameter umbi.

\section{KESIMPULAN}

Berdasar pada uraian tersebut di atas, maka dapat disimpulkan bahwa :

1. Pemberian $\mathrm{N}$ dosis $135 \mathrm{~kg} \mathrm{ha}^{-1}$ yang diikuti dengan pemangkasan tajuk 1 kali, bobot umbi per tanaman yang dihasilkan paling tinggi, yaitu sebesar 298,54 g.

2. Pemberian $\mathrm{N}$ pada dosis yang paling tinggi $\left(202,5 \mathrm{~kg} \mathrm{ha}^{-1}\right)$ hanya menghasilkan komponen pertumbuhan yang paling tinggi, yaitu luas daun dan masa luas daun. 
3. Perlakuan tanpa pemangkasan tajuk hanya menghasilkan komponen pertumbuhan yang paling tinggi, yaitu luas daun dan masa luas daun.

4. Pemangkasan tajuk 2 hingga 3 kali menyebabkan rendahnya komponen hasil maupun bobot umbi yang dihasilkan.

\section{SARAN}

Pada budidaya tanaman ubi jalar, untuk mendapatkan hasil umbi yang tinggi disarankan dosis pupuk urea yang digunakan sekitar $300 \mathrm{~kg}$ urea $\mathrm{ha}^{-1}$ atau setara dengan $135 \mathrm{~kg} \mathrm{~N} \mathrm{ha}^{-1}$ yang diikuti dengan pemangkasan tajuk 1 kali, yaitu pada umur 35 hari setelah tanam.

\section{UCAPAN TERIMAKASIH}

Pada kesempatan ini penulis menyampaikan banyak terimakasih kepada Pak Wawan yang telah banyak membantu penulis ketika melakukan kegiatan di lapangan.

\section{DAFTAR PUSTAKA}

Alam, M.S., S. M. Imran, M.A. Sattar, M.R. Islam, M.M.A. Hossain.2010. Effect of different organic and inorganic fertilizers on growth and (Colocasia esculenta) cv. sali kachu. Agrofor. Environ. 4 (2): 53-56.

Bartolini, P.U. 1982. Timing and frequency of topping sweet potato at varying levels of Nitrogen. Dalam Villareal, R.L. and Griggs (Ed.) sweet potato, proc., The first Int. Symp. AVDC. Taiwan China. 209-214.

Evans, C.G. 1972. The quantitative analysis of plant growth. University of California. Pp. 734.
Gomez, A.A dan A.K. Gomez. 1983. Statistical Procedures for Agricultural Research. $2^{\text {nd }}$ Ed. John Wiley \& Sons. New York. p. 188207.

Pahlevi, R.W., N.E. suminarti, B. Guritno. 2015. Pengaruh kombinasi pemupukan $N$ dan $\mathrm{K}$ pada pertumbuhan dan hasil tanaman ubi jalar (Ipomoea batatas L.(Lam.) var. Cilembu di dataran rendah. J. Produksi Tanaman (4) : 4-14.

Purnamaningsih, R., N.E. Suminarti, Ariffin. 2009. Pengaruh pemupukan N dan K pada tanaman talas (Colocasia esculenta L.) Schott var. Antiquorum. J. Produksi tanaman (2) : 17-24.

Ranjha, A. M., M. Ul-Hassan, M. Maqsood, S.A. Wajid. 2016. Impact of moisture stress and Nitrogen use efficiency, and harvest index of Cotton (Gossypium hirsutum L.). Pak. J. Agri.Sci. Vol. 53 (1) 171-180.

Sitompul, S.M. dan B. Guritno. 1995. Analisis Pertumbuhan Tanaman. FP.UB. Gajah Mada Press. p. 38-45.

Sitompul, S.M. 2016. Analisis Pertumbuhan tanaman. New. Ed. UB. Press.

Suminarti, N.E., Ariffin, B. Guritno and M.L. Rayes. 2016. Effect of fertilizer application and plant density on physiological aspect and yield of Taro (Colocasia esculenta (L.) Schott var.Antiquorum). Int. J. of Agric. Res. 11 (1) : 32-39.

Tsuno,Y. 1980. Sweet potato, nutrient physiology and cultivation. Fac.of Agric. Ehime Univ., Japan.Ed. : Inter. Potash Institute berne, Switzerland : 1-7. 